\title{
DESAIN INSTRUMEN TES KEMAMPUAN PEMECAHAN MASALAH MATEMATIS BERBASIS GAME UNITY
}

\author{
Riqi Kurniawan ${ }^{1 *}$, Hamidah Suryani Lukman ${ }^{2}$, Novi Andri Nurcahyono ${ }^{3}$ \\ Program Studi Pendidikan Matematika, Universitas Muhammadiyah Sukabumi \\ Email: rikurniawan019@ummi.ac.id
}

Diterima: 02 Juni 2021. Disetujui: 15 Juni 2021. Dipublikasikan: 31 Juli 2021

\begin{abstract}
ABSTRAK
Penelitian ini bertujuan untuk mengetahui proses merancang instrumen tes dan menghasilkan desain instumen tes kemampuan pemecahan masalah matematis berbasis game unity. Metode penelitian yang digunakan yaitu Research and Development dengan menggunkan model ADDIE. Tahapan ADDIE yang digunakan yaitu tahap analyze dan Design. Analisis dilakukan dengan tahapan perumusan masalah, mengumpulkan data, mengevaluasi kelayakan data, menganalisis dan menginterpretasi data yang relevan, dan mengatur serta menyajikan hasil yang kemudian hasil yang diperoleh dibandingkan dengan isu-isu saat ini, sedangkan desain dilakukan dengan tahapan membuat desain hipotetik, kemudian dikembangkan menjadi desain tampilan menggunakan software. Adapun hasil yang diperoleh yaitu proses perancangan instrument tes kemampuan pemecahan masalah matematis berbasis game unity dapat dirancang dengan tahapan pencarian soal-soal tes kemampuan pemecahan masalah matematis yang sudah valid, pembuatan flowchart, perancangan, serta pembuatan aplikasi menggunakan game engine unity. Desain instrument tes dibuat menggunakan unity game engine, penyajian masalah dibuat dalam bentuk gambar dan petunjuk serta pengisian jawaban menggunakan tahapan IDEAL problem solving.
\end{abstract}

Kata kunci: Pemecahan Masalah, Gamifikasi, Unity, Instrumen Tes

\begin{abstract}
This study aims to find out the process of designing test instruments and produce instrument design test mathematical problem-solving ability based on game unity. The research method used is Research and Development by using the Addie model. ADDIE stage used is analyze and Design. The analysis is carried out by the stages of problem formulation, collecting data, evaluating data feasibility, analyzing and interpreting relevant data, and organizing and presenting results that are then obtained compared to current issues, while the design is done by making hypothetical designs, then developed into a display design using the software. The results obtained are the process of designing instrument test mathematical problem-solving ability based on game unity can be designed with the stages of searching for valid mathematical problem-solving ability test or create a problem that is then validated, flowchart creation, design, and application creation using game engine unity. Test instrument design is made using a unity game engine, problem presentation is made in the form of images and instructions, and filling answers using ideal problem-solving stages.
\end{abstract}

Keywords: Problem Solving, gamification, Unity, Tes Instrument

\section{Pendahuluan}

Peraturan Menteri Pendidikan Republik Indonesia No. 22 Tahun 2016 menyebutkan bahwa siswa harus didorong untuk memiliki kemampuan pemecahan masalah. Polya (Hendikawati et al, 2019) menyampaikan bahwa kemampuan pemecahan masalah dapat diartikan sebagai suatu usaha untuk mencari jalan keluar dari suatu permasalahan untuk mencapai suatu tujuan yang tidak mudah. Kemampuan pemecahan masalah matematis juga merupakan komponen sangat penting karena merupakan jantungnya dalam proses belajar matematika (Dewi \& Minarti, 2018; Prasetya et al., 2012). Menurut Pehkoen (dalam Setiawan \& Harta, 2014) alasan mengapa pemecahan masalah penting dipelajari yaitu : (1) dapat mengembangkan keterampilan kognitif, (2) dapat meningkatkan 
kreativitas, (3) merupakan bagian dari proses aplikasi matematika, dan (4) dapat memotivasi siswa untuk belajar matematika. Sebagaimana yang disampaikan oleh (Zulfah, 2017) yang menyebutkan bahwa siswa diharuskan mempunyai kemampuan memecahkan masalah matematika sebagai sarana untuk mengasah penalaran yang cermat, logis, kritis, analitis, dan kreatif.

Kemampuan pemecahan masalah matematis tidak dapat dilihat secara langsung. Untuk mengetahui kemampuan pemecahan masalah siswa, diperlukan sebuah pengujian. Pengujian yang dilakukan oleh guru saat ini masih menggunakan teori tes klasik yang berupa tes tulis yang berbentuk soal pilihan ganda dan essay. Kekurangan tes klasik yang ada saat ini adalah bentuk soal yang kurang variatif sehingga kurang memacu kemampuan berpikir siswa khususnya dalam pemecahan masalah (Edy \& Tandilling, 2012). Terdapat bebarapa faktor yang mempengaruhi kemampuan pemecahan masalah matematis yaitu konteks soal, rumus, penguasaan materi, pemahaman, dan sebagaianya (Kudsiyah, et al 2017).

Pada era revolusi industry 4.0 atau era digitalisasi, pembelajaran di sekolah sudah mulai berpindah menggunakan perangkat berbasis teknologi. Pengembangan modul, media, maupun perangkat pembelajaran matematika lainnya yang berbasis teknologi informasi sudah banyak bermunculan, termasuk produk pemerintah terkait Ujian Nasional Berbasis Komputer (UNBK) yang beberapa tahun terakhir selalu digunakan. Sedangkan pengembangan instrumen tes yang spesifik dalam mengukur kemampuan pemecahan masalah matematis siswa yang berbasis teknologi masih sangat jarang. Salah satu kendalanya disebabkan oleh pemahaman guru terkait analisis soal dengan pendekatan modern masih kurang (Hasnah, 2017).

Perlu adanya pembaruan dalam mengukur kemampuan pemecahan masalah matematis siswa, supaya meningkatkan minat siswa untuk dapat memecahkan masalah matematika. Salah satunya melalui pembuatan instrument tes kemampuan pemecahan masalah matematis yang terkolaborasi gamifikasi. Gamifikasi merupakan metode yang mengacu pada proses memperkenalkan, mengubah, dan mengoperasikan sistem pelayanan serta interkasi antara manusia dan komputer yang banyak mengambil inspirasi dari komponen mechanical game dan elemen-elemen game yang membuat proses pembelajaran lebih menyenangkan, karena memasukan unsur game, juga untuk mengikat, memotivasi, dan menyelesaikan masalah siswa dalam pembelajaran (Farida, 2018; Farozi, 2016; Jusuf, 2016; Prambayun et al., 2016).

Proses menyusun suatu game yang berbasis teknologi diperlukan suatu aplikasi pembuat game. Salah satu aplikasi yang dapat digunakan yaitu Unity. Unity merupakan aplikasi pembuat game yang memberikan keuntungan yang baik dibandingkan aplikasi lainnya, karena unity memberikan pengembangan grafik 3D dan 2D, menyediakan seperangkat peralatan yang selalu mendapat pembaharuan dan fitur lainnya (Nasution et al., 2019). Mengingat latar belakang di atas, penelitian ini bertujuan untuk mengetahui bagaimana merancang instrument tes dan menghasilkan desain instumen tes kemampuan pemecahan masalah matematis berbasis game unity.

\section{Metode Penelitian}

Metode penelitian yang digunakan adalah metode R\&D (Research and Development) dengan menggunakan model ADDIE. Tahapan dari model pengembangan ADDIE ini adalah terdiri dari (1) Analyze (analisis), (2) Design (perencanaan), (3) Develop (pengembangan), (4) Implement (implementasi), dan (5) Evaluate (evaluasi) (Kurniawan et al., 2018). Dalam artikel ini, penelitian hanya terbatas pada tahap analisis dan desain yang bertujuan untuk menganalisis bagaimana merancang instrument dan menghasilkan desain dari instrument tes kemampuan pemecahan masalah matematis berbasis game unity. Penelitian ini dibatasi karena pada pelaksaannya tidak dapat melakukan implemetasi pada saat covid-19, sehingga terbatas.

Pada tahap analisis, dilakukan kajian literatur mengenai Instrument tes sebanyak 4 Artikel, Gamifikasi sebanyak 8 artikel, IDEAL problem solving sebanyak 8, dan Unity sebanyak 5 artikel. Kajian yang dilakukan meliputi pengembangan dan pembelajaran. Analisis dilakukan dengan tahapan (1) merumuskan masalah, (2) mengumpulkan data, (3) mengevaluasi kelayakan data, (4) menganalisis dan menginterpretasi data yang relevan, dan (5) mengatur serta menyajikan hasil yang kemudian hasil yang diperoleh dibandingkan dengan isu-isu saat ini (Suhartono, 2017). Tahap berikutnya adalah Desain (peracangan) untuk merancang instrumen tes berbasis game unity. Proses pembuatan desain 
terdiri dari membuat desain hipotetik berbentuk bagan alur, kemudian dikembangkan menjadi desain tampilan menggunakan softwere. Apabila dilakukan pembuatan soal sendiri maka dilakukan validasi kepada ahli materi, kemudian apabila sudah tervalidasi maka dapat dipakai dalam game. Pada penelitian ini soal yang digunakan merupakan soal yang sudah tervalidasi.

\section{Hasil Penelitian dan Pembahasan}

Berdasarkan pemaparan metode penelitian, penelitian terdiri atas tahap analisis yang meliputi analisis proses perancangan instrumen tes dan tahap perancangan desain instrument tes kemampuan pemecahan masalah matematis berbasis game unity.

A. Analisis

Pada tahap ini dilakukan proses menganalisis, mengevaluasi dan mensintesis bagaimana proses perancangan instrumen tes kemampuan pemecahan masalah matematis berbasis game unity. Analisis yang dilakukan yaitu melalui kajian literatur. Literatur dikumpukan melalui pencarian dari database Science Direct dan Google Scholar. Literatur yang di kumpulkan kemadian di skrinning berdasarkan abstak dan tahun terbit yaitu 5 tahun terakhir. Kemudian dilakukan analisis dan sintesis dengan hasil sebagai berikut.

Gamifikasi adalah sebuah pendekatan pembelajaran yang menggunakan permainan atau visualisasi bergerak yang dirancang khusus untuk mengajari keahlian tertentu bagi siswa, sehingga didalam proses pembelajarannya menggunakan pemikiran untuk memotivasi siswa menyelesaikan masalah (Farida, 2018; Jusuf, 2016; Prambayun et al., 2016; Pujakusuma et al., 2018). Salah satu bentuk gamifikasi yang dapat diterapkan dalam pembelajaran adalah dalam pembuatan instrument tes berbasis teknologi informasi. Salah satu Aplikasi yang dapat digunakan untuk membuat instrument tes kemampuan pemecahan matematis siswa adalah Game Unity.

Unity merupakan aplikasi pembuat game yang memberikan keuntungan yang besar dibandingkan aplikasi lainnya, hal ini disebabkan karena unity memberikan kapabilitas drag-anddrop pada alur kerja visualnya serta mendukung pemograman bahasa $\mathrm{C \#}$, pengembangan grafis 3D dan 2D, menyediakan seperangkat peralatan yang selalu mendapat pembaharuan (Nasution et al., 2019). Beberapa hasil penelitian pengembangan menggunakan unity yang telah berhasil diujicoba mencapai 70\%. Produk yang dikembangkan berhasil membantu memahami materi, meningkatkan minat belajar siswa dan menghibur. Pengembangan tersebut telah memiliki nilai efektifitas, efisiensi, dan daya tarik untuk digunakan (Adiqro, 2018; Ramansyah, 2016; Susanto et al., 2016).

Adapun proses perancangan instrumen tes berbasis game unity dimulai dengan proses pencarian soal-soal yang sudah tervalidasi dan membuatan soal-soal kemudian divalidasi dan di uji coba sehingga soal-soal tersebut memenuhi kriteria valid dan reliabel. Soal-soal yang digunakan yaitu soal pada materi yang terdapat pada jengjang SMP. Model pemecahan masalah yang digunakan yaitu IDEAL problem solving dikarenakan didesain untuk membantu mengidentifikasi dan memahami bagian-bagian yang berbeda dari penyelesaian masalah, masing-masing huruf melambangkan komponen penting dalam proses penyelesaian masalah yaitu I-Identify problem, D-Define goal, E-Explore possible strategies, A-Act on the strategy, LLook back, and evaluate the effect (Yanti \& Syazali, 2016). Beberapa soal dalam sub materi mata pelajaran matematika yang dijadikan rujukan untuk digunakan dalam proses perancangan ini yaitu soal dalam materi persamaan linier satu variable dan pertidaksamaan linier satu variable yang memiliki validitas soal pada rentang skor pada tiap soal sebesar 6,089 hingga 11,422 yang dikategorikan valid kemudian reliabilitas soal sebesar 0,876 yang diatagorikan pada reliabilitas tinggi (Indriyani et al., 2018)

Selanjutnya dilakukan tahapan desain yang dimulai dengan pembuatan flowchart atau diagram alir menu awal dan menu-menu lainnya. Setelah pembuatan flowchart, tahapan selanjutnya adalah pembuatan desain tampilan game yang bertujuan untuk membantu membuat aplikasi sehingga sesuai dengan gambaran awal yang diharapkan. Setelah proses pembuatan desain, dibutlah prototype menu awal dalam aplikasi. Pembuatan ini menggunakan aplikasi unity engine sebagai alat untuk merakit aplikasi. Menu-menu yang disediakan pada panel menu awal 
aplikasi ini adalah terdiri empat menu utama yaitu menu play, menu level, menu materi, dan menu quit yang berbentuk tombol yang dapat di klik oleh user (A. R. Dewi et al., 2015; Patil \& Alvares, 2015; Pujakusuma et al., 2018).

B. Desain

Tahap selanjutnya adalah tahap desain, pada tahap ini dilakukan penyusunan dan perancangan intrumen tes kemampuan pemecahan masalah matematis berbasis game unity yang dikemas dalam bentuk game. instrumen merupakan alat untuk mengukur semua fenomena sosial maupun alam yang diamati atau yang disebut variabel (Sugiyono, 2017). Pengembangan instrument yang berbasis teknologi sudah banyak bermunculan. Sedangkan pengembangan yang terkolaborasi dengan gamifikasi masih jarang. Dalam intrumen tes ini mengahadirkan sebuah intrumen yang terkolaborasi dengan gamifikasi. Dalam intrumen tes ini juga soal-soal latihan yang harus dikerjakan oleh siswa dengan tuntunan pengisian menggunakan indikator Ideal problem Soving. Dalam instrument ini juga terdapat berbagai jenis soal dari materi yang berbeda agar instumen tidak hanya digunakan dalam satu materi tertentu saja. Contoh tampilan pengembanan intrumen tes kemampuan pemecahan masalah matematis berbasis game unity dapat dilihat pada Desain Hipotetik Gambar 1.

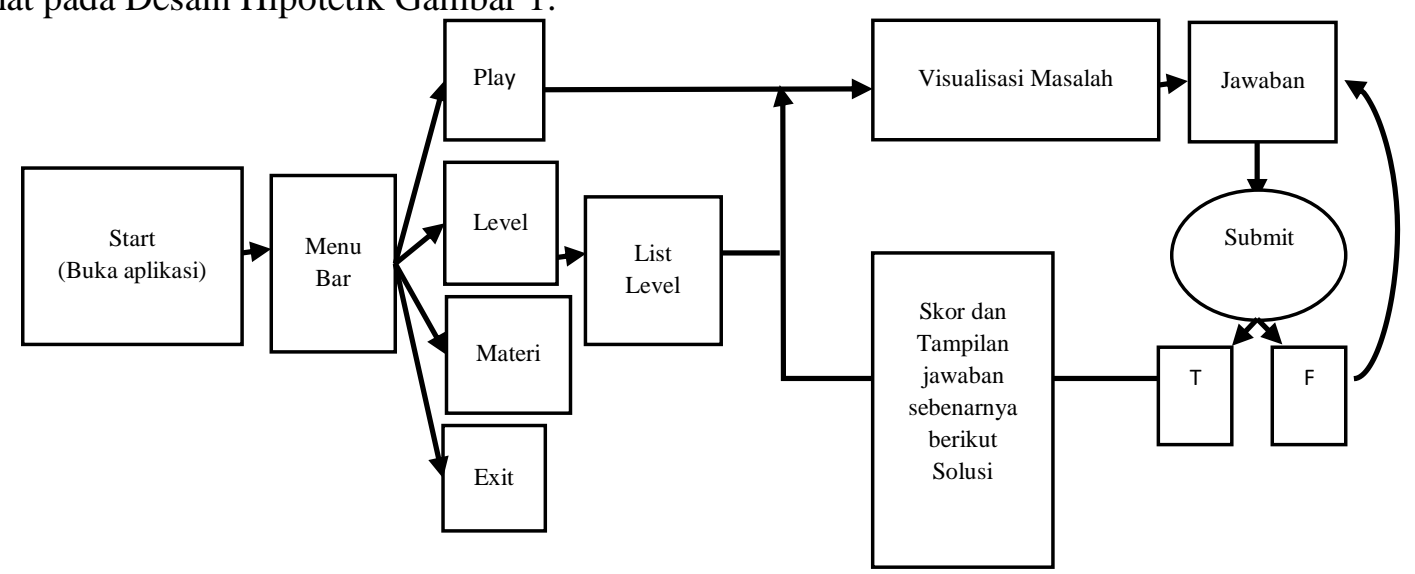

Gambar 1. Desain Hipotetik Instrumen Tes Kemampuan Pemecahan masalah Berbasis Game Unity

Pada tampilan menu utama terdapat beberapa menu yang dapat dipilih oleh siswa. Menu tersebut yaitu ada menu play untuk memulai game. kemudian ada menu level yaitu terdapat daftar level yang akan dilalui siswa dan siswa dapat memulai permainan selain dari menu play. Terdapat juga menu materi yaitu daftar meteri yang dapat dipilih oleh siswa. Kemudian terdapat menu exit untuk menutup game. Desain menu utama dapat dilihat pada Gambar 2.

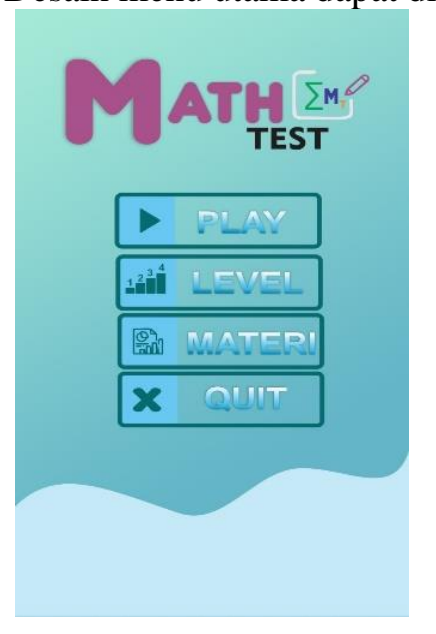

Gambar 2. Panel Menu Utama 
Secara umum dalam pengembangan instrument tes ini berisi tentang latihan soal yang harus dikerjakan oleh siswa. Soal-soal yang digunakan adalah soal-soal yang sudah tervalidasi. Hal ini dikarenakan soal yang dibuat harus sesuai dengan indikator pemecahan masalah yang inginkan. Visualiasi malasah yang dihadirkan dalam instrumen ini berbentuk gambar dan petunjuk, supaya siswa mudah memahami masalah yang terdapat dalam soal. Selain itu siswa menyelesaikan masalah harus mengikuti tahapan menjawab sesuai dengan tahapan pemecahan masalah Ideal Problem Soving yang tersedia. Contoh tampilan latihan soal dan cara pengsisian dari pengembanan intrumen tes kemampuan pemecahan masalah matematis berbasis game unity dalap dilihat pada Gambar 3.

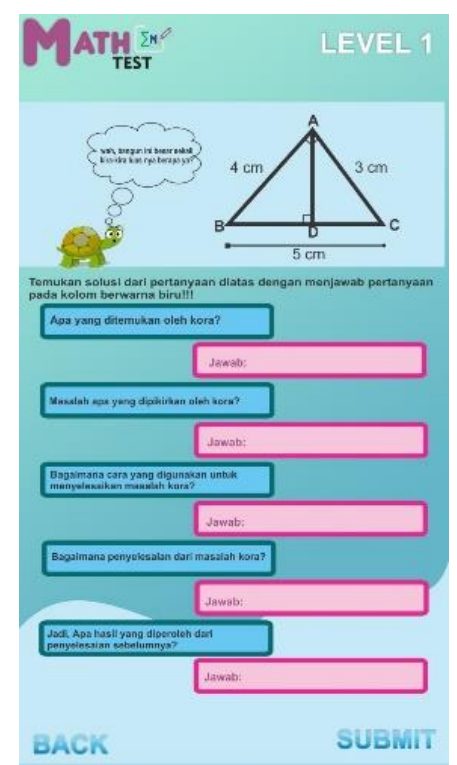

\section{Gambar 3. Panel Visualisasi Masalah}

Pada pengembangan instrument ini juga terdapat salah dan benar seperti pada game pada umumnya. Setelah siswa selesai mengisi kelima kolom yang disediakan kemudian siswa mensubmit jawaban. Setelah di submit maka siswa akan mendapat dua hasil, jika siswa menjawab benar semua maka akan muncul panel benar dan selanjutkan akan keluar jawaban dari masalah yang disajikan seperti pada Gambar 4. Akan tetapi jika jawaban siswa salah, maka akan muncul panel salah dan akan muncul panel instruksi pengisisan seperti pada Gambar 5, kemudian siswa harus mengulangi panel soal untuk kembali menyelesaikan masalah.

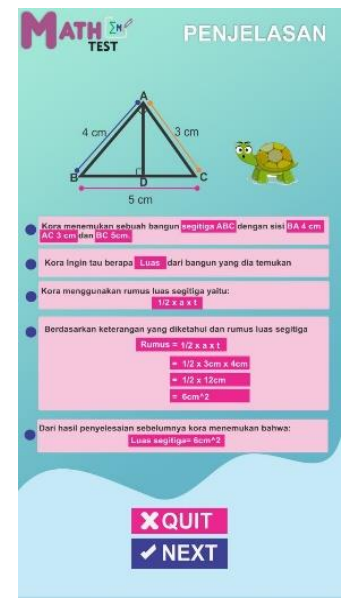

Gambar 4.

Panel ketika Menjawab Benar

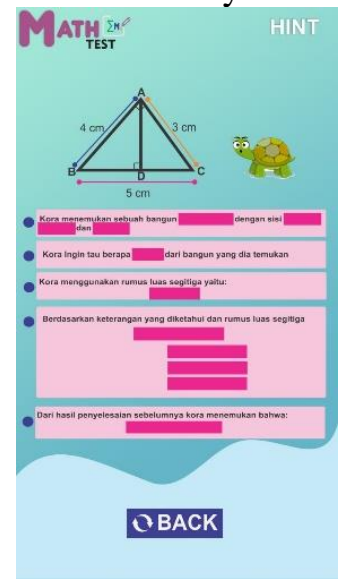

Gambar 5.

Panel Ketika Menjawab Salah 


\section{Kesimpulan}

\section{Simpulan}

1. Perancangan intrumen test kemampuan pemecahan masalah matematis berbasis game unity dapat dimulai dengan pencarian soal dari karya ilmiah atau pembuatan soal-soal tes kemampuan pemecahan masalah matematis kemudian di validasi, pembuatan flowchart, pembuatan aplikasi menggunakan game engine unity, serta pengujian kualitas instrument yang dikembangkan supaya diperoleh instrumen tes yang valid.

2. Desain intrumen tes yang dihasilkan berbentuk game yang dibuat menggunakan unity game engine serta penyajian pertanyaan atau masalah dalam intrumen ini dikemas dalam bentuk konsep matematika dan sudah tervalidasi sesuai dengan indikator pemecahan masalah yang inginkan. Visualiasi malasah yang dihadirkan dalam intrumen ini berbentuk gambar dan petunjuk, supaya siswa mudah memahami masalah yang terdapat dalam soal. Selain itu siswa menyelesaikan masalah mengikuti tahapan menjawab sesui dengan tahapan pemecahan masalah Ideal problem Soving.

\section{Saran}

Direkomendasikan untuk penelitian selanjutnya tahapan pengembangan instrumen dilanjutkan sampai kepada tahapan implementasi dan kemudian tahapan evaluasi sehingga hasil pengembangan instrumen ini dapat diketahui efektifitasnya. Selain itu direkomendasikan pengembangan instrumen ini di kembangkan pada kemampuan matematis lainnya.

\section{Daftar Pustaka}

Adiqro, A. F. (2018). Aplikasi Pembelajaran Menulis Permulaan Berbasis Android Menggunakan Unity 2D. Journal of Information and Technology, 6(1), 53-62.

Dewi, A. R., Isnanto, R. R., \& Martono, K. T. (2015). Aplikasi Multimedia sebagai Media Pembelajaran Ilmu Pengetahuan Sosial Materi Budaya di Indonesia menggunakan Unity Engine untuk Sekolah Dasar. Jurnal Teknologi Dan Sistem Komputer, 3(4), 471. https://doi.org/10.14710/jtsiskom.3.4.2015.471-480

Dewi, S. N., \& Minarti, E. D. (2018). Hubungan Antara Self-Confidence Terhadap Matematika Dengan Kemampuan Pemecahan Masalah Ssiswa Pada Materi Lingkaran. Unnes Journal of Mathematic Education, 7, 1.

Edy, \& Tandilling. (2012). Regulated Learning Siswa dalam pembelajaran matematik di sekolah menengah atas. Jurnal Penelitian Pendidikan, 13(1), 24-31.

Farida, Y. K. W. Y. P. (2018). Pengembangan Bahan Ajar Gamifikasi pada Materi Bangun Ruang Sisi Lengkung. JPPM, 11(2), 193-204.

Farozi, M. (2016). Rancangan Bangun Website Gamifikasi Sebagai Hasil Belajar Mahasiswa Studi Kasus: Amik Lembah Dempo Pagar Alam. Seminar Nasional Teknologi Informasi Dan Multimedia 2016, 6-7.

Hasnah. (2017). Analisis Kualitas Soal Matematika Ujian Sekolah Kelas XII IPA SMA Negeri di Watansoppeng Berdasarkan Teori Respon Butir. 1(1), 27-33.

Hendikawati, P., Zahid, M. Z., \& Arifudin, R. (2019). Keefektifitas Media Pembelajaran Berbasis Android terhadap Kemampuan Pemecahan Masalah dan Kemandirian Belajar. PRISMA, 2. https://journal.unnes.ac.id/sju/index.php/prisma/article/view/29308/12927

Indriyani, F., Nurcahyono, N. A., \& Nur, A. (2018). Analisis Kemampuan Pemecahan Masalah Siswa Berdasarkan Langkah Ideal Problrm Solving. PYTHAGORAS, 7. https://www.journal.unrika.ac.id/index.php/jurnalphythagoras/article/view/1296

Jusuf, H. (2016). Penggunaan Gamifikasi dalam Proses Pembelajaran. Jurnal TICOM, 5(1), 1-6. https://media.neliti.com/media/publications/92772-ID-penggunaan-gamifikasi-dalam-proses- 
pembe.pdf

Kudsiyah, S. M., Novarina, E., \& Lukman, H. suryani. (2017). Faktor-Faktor Yang Mempengaruhi Kemampuan Pemecahan Masalah Matematika Kelas X Di Sma Negeri 2 Kota Sukabumi. Education: Prodi Pendidikan Matematika FKIP Universitas Muhammadiyah Sukabumi, 110 117.

Kurniawan, B. R., Reyza, M., \& Taqwa, A. (2018). Pengembangan Instrumen Tes Kemampuan Pemecahan Masalah Fisika pada Materi Listrik Dinamis. 3(11), 1451-1457.

Nasution, S., Nasution, A. H., \& Hakim, A. L. (2019). Pembuatan Plugin Tile-Based Game Pada Unity 3D. It Journal Research and Development, 4(1), 46-60. https://doi.org/10.25299/itjrd.2019.vol4(1).3517

Patil, P. P., \& Alvares, R. (2015). Cross-platform Application Development using Unity Game Engine. International Journal of Advance Research in Computer Science and Management Studies, 3(4), 1-9. https://www.researchgate.net/publication/312591645

Prambayun, A., Suyanto, M., \& Sunyoto, A. (2016). Model gamifikasi untuk sistem manajemen pembelajaran. Seminar Nasional Teknologi Informasi Dan Multimedia, 6-7.

Prasetya, A., Kartono, \& Widodo, A. T. (2012). Model Ideal Problem Solving Untuk Pencapaian Kemampuan Pemecahan Masalah di Kelas Olimpiade. LIK, 41, 2. http://journal.unnes.ac.id/nju/index.php/LIK

Pujakusuma, G. A., Haryanto, D., Wirandhanu, M. I., \& Pramudya, S. A. (2018). Game "Incredible Math" Berbasis Android sebagai Media Pembelajaran Virtual Reality. Prosiding SNMPM II, Prodi Pendidikan Matematika, Unswagati.

Ramansyah, W. (2016). Pengembangan Game Edukasi "Aksara Jawa" Berbasis Unity untuk Siswa Kelas 3 SDN Mulyoarjo 3 Lawang. Edutic.

Setiawan, R. H., \& Harta, I. (2014). Pengaruh Pendekatan Open-Ended dan pendekatan Kontekstual Terhadap Kemampuan Pemecahan Masalah dan Sikap Siswa Terhadap Matematika. Jurnal Riset Pendidikan Matematika, 1, 2.

Sugiyono. (2017). Metode Penelitian kuantitatif, Kualitatif, dan $R \& D$ (Sugiyono (ed.)). Alfabeta.

Suhartono, E. (2017). Systematic Literatur Review ( SLR ): Metode, Manfaat, Dan Tantangan Learning Analytics Dengan Metode Data Mining di Dunia Pendidikan Tinggi. Jurnal Ilmiah INFOKAM, 13(1), 73-86.

Susanto, D., Basuki, A., \& Hakim, D. R. (2016). Mobile Augmented Reality Untuk Pembelajaran IPA Kelas 7 Kurikulum 2013. Prosiding SENTIA 2016, 8(2011), 69-74.

Yanti, A. P., \& Syazali, M. (2016). Analisis Proses Berpikir Siswa dalam Memecahkan Masalah Matematika Berdasarkan Langkah-Langkah Bransford dan Stein Ditinjau dari Adversity Quotient. Al-Jabar: Jurnal Pendidikan Matematika, 7(1), 63-74.

Zulfah. (2017). Pengaruh Penerapan Model Pembelajaran Kooperatif Tipe Think Pair Share Dengan Pendekatan Heuristik Terhadap Kemampuan Pemecahan Masalah Matematis Siswa MTs Negeri Naubai Kecamatan Kampar. Journal Cendikia, 1, 2. 